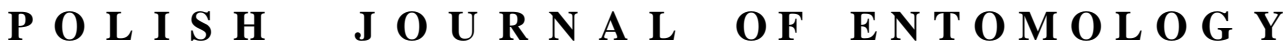

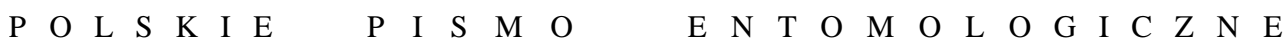

VOL. 84: $311-323$

Lublin

30 December 2015

DOI: $10.1515 /$ pjen-2015-0027

\section{Orchard aphids (Hemiptera: Sternorrhyncha, Aphidoidea) of Lithuania: a century of research*}

\author{
RIMANTAS RAKAUSKAS \\ Department of Zoology, Vilnius University, Čiurlionio 21/27, Vilnius, LT 03101, \\ Lithuania, e-mail: rimantas.rakauskas@gf.vu.lt
}

\begin{abstract}
The current state of knowledge on the composition of aphid species inhabiting horticultural crops in Lithuania is summarized, with notes on their taxonomy and the biological peculiarities of Lithuanian populations of particular species.
\end{abstract}

KEY WORDS: aphids, orchard pests, fauna, biology, Lithuania.

\section{INTRODUCTION}

The first data concerning the aphid species inhabiting horticultural crops in Lithuania appeared at the beginning of the last century (KRIŠČIŪNAS 1913, TRZEBIŃSKI 1916; for more references of that period see RAKAUSKAS et al. 1992). Results of special studies of horticultural pests, including some aphid species, were also published (MASTAUSKIS \& Vilkaitis 1929, OGIJEWICZ 1929, 1931). More detailed faunistic studies of dendrophilous aphids (including horticultural ones) were started in the second half of the $20^{\text {th }}$ century (RUPAIS 1966, 1971, RUPAIS \& JURONIS 1983a, 1983b, VENGELIAUSKAITE 1962, RAKAUSKAS 1978, 1980, 1981). In addition, data on host specificity, life cycles and natural enemies of Lithuanian populations of certain horticultural pest aphid species were also reported (RAKAUSKAS 1983a, 1983b, 1984, 1986, 1993, 1996, RAKAUSKAS \& RUPAIS

\footnotetext{
* The paper is dedicated to Prof. Wacław WOJCIECHOWSKI in recognition of his great contribution to the taxonomy and faunistics of Hemiptera.
} 
1983, RAKAUSKAS \& ZAJANČKAUSKAS 1983, RAKAUSKAS \& TURČINAVIČIENĖ 1998, TURČINAVIČIENĖ 2000, BAŠILOVA 2006). Later on, although closer attention was now being paid to taxonomic and phylogenetic studies (RAKAUSKAS 1998, 1999, 2000a, 2000b, 2003a, 2003b, 2003c, 2006, TURČINAVIČIENĖ et al. 1997, 1999, RAKAUSKAS \& CICHOCKA 2005, RAKAUSKAS \& TURČINAVIČIENĖ 2006, TURČINAVIČIENĖ et al. 2006, BAŠILOVA et al. 2008, 2012, TURČINAVIČIENĖ \& RAKAUSKAS 2009, BAŠILOVA 2010a, BAŠILOVA 2010b, BAŠILOVA \& RAKAUSKAS 2007, 2012a, 2012b, RAKAUSKAS et al. 2011, 2013, 2014a, 2014b), faunistic studies were continuing (for a broader account of faunistic references, see RAKAUSKAS 2011, 2014). At the beginning of the $21^{\text {st }}$ century alien and invasive aphid species in Lithuania were studied (RAKAUSKAS 2004, 2011, BAŠILOVA \& RAKAUSKAS 2012c, BAŠILOVA et al. 2012, RAKAUSKAS et al. 2015a). In all, 58 aphid species feeding on horticultural crops have been reported from Lithuania, 18 of which constitute a real threat to horticulture in the country and have been subject to detailed morphological, taxonomical, life cycle and host specificity studies.

The present report aims to summarize the current state of knowledge on the composition of aphid species inhabiting horticultural crops in Lithuania, their taxonomy and the biological peculiarities of Lithuanian populations of particular species.

\section{RESULTS AND DISCUSSION}

At present, 58 aphid species are reported as inhabiting horticultural crops in Lithuania (Table 1). Eleven of these species are associated with stone fruit crops (Prunoideae), 19 with pome fruit crops (Pyroideae), 6 with host plant species of the genus Rubus LINNAEUS, 1753, 15 with Ribes LinNAEUS, 1753 and 8 with Rosa LinNAEUS, 1753. A short review on the available information relating to the morphological features, biology and ecology of Lithuanian populations of orchard aphid species now follows. Particular emphasis is placed on characteristics that differing from what is commonly known about these species (BLACKMAN \& EASTOP 2000).

Table 1. Taxonomic composition and incidence of aphid species on horticultural crops in Lithuania (the most common species are given in bold). A - Prunoidea, B - Pyroideae, C - Rubus, D - Ribes, E-Rosa.

\begin{tabular}{|r|l|c|c|c|c|c|}
\hline No & \multicolumn{1}{|c|}{ Aphid species } & A & B & C & D & E \\
\hline 1. & Amphorophora idaei (BÖRNER, 1939) & & & + & & \\
\hline 2. & A. rubi (KALTENBACH, 1843) & & & + & & \\
\hline 3. & Anuraphis catonii HILLE RIS LAMBERS, 1935 & & + & & & \\
\hline 4. & A. farfarae (KOCH, 1854) & & + & & & \\
\hline
\end{tabular}


Table 1. Continued.

\begin{tabular}{|c|c|c|c|c|c|c|}
\hline No & Aphid species & $\mathbf{A}$ & $\mathbf{B}$ & $\mathbf{C}$ & D & $\mathbf{E}$ \\
\hline 5. & Anuraphis subterranea (WALKER, 1849) & & + & & & \\
\hline 6. & Aphis craccivora $\mathrm{KoCH}, 1854$ & & + & & & \\
\hline 7. & A. grossulariae KALTENBACH, 1843 & & & & + & \\
\hline 8. & A. idaei VAN DER GOOT, 1912 & & & + & & \\
\hline 9. & A. pomi DE GEER, 1773 & & + & & & \\
\hline 10. & A. ruborum (BÖRNER, 1932) & & & + & & \\
\hline 11. & A. schneideri (BÖRNER, 1940) & & & & + & \\
\hline 12. & A. triglochinis (THEOBALD, 1936) & & & & + & \\
\hline 13. & A. spiraecola PATCH, 1914 & + & + & & & \\
\hline 14. & Brachycaudus cardui (LINNAEUS, 1758) & + & & & & \\
\hline 15. & B. divaricatae SHAPOSHNIKOV, 1956 & + & & & & \\
\hline 16. & B. helichrysi (KALTENBACH, 1843) & + & & & & \\
\hline 17. & Chaetosiphon tetrarhodum (WALKER, 1849) & & & & & + \\
\hline 18. & Cryptomyzus galeopsidis (KALTENBACH, 1843) & & & & + & \\
\hline 19. & C. korschelti BÖRNER, 1938 & & & & + & \\
\hline 20. & C. maudamanti GULDEMOND 1990 & & & & + & \\
\hline 21. & C. ribis (LINNAEUS, 1758) & & & & + & \\
\hline 22. & Dysaphis affinis (MORDVILKO, 1928) & & + & & & \\
\hline 23. & D. anthrisci BÖRNER, 1950 & & + & & & \\
\hline 24. & D. brancoi BÖRNER, 1950 & & + & & & \\
\hline 25. & D. crataegi (KALTENBACH, 1843) & & + & & & \\
\hline 26. & D. devecta (WALKER, 1849) & & + & & & \\
\hline 27. & D. plantaginea (PASSERINI, 1860) & & + & & & \\
\hline 28. & D. pyri (BOYER DE FONSCOLOMBE, 1841) & & + & & & \\
\hline 29. & D. sorbi (KALTENBACH, 1843) & & + & & & \\
\hline 30. & Eriosoma grossulariae (SCHÜLE, 1887) & & & & + & \\
\hline 31. & E. lanigerum (HAUSSMAN, 1802) & & + & & & \\
\hline 32. & E. lanuginosum (HARTIG, 1839) & & + & & & \\
\hline 33. & E. ulmi (LINNAEUS, 1758) & & & & + & \\
\hline 34. & Hyalopterus pruni (GEOFFROY, 1762) & + & & & & \\
\hline 35. & Hyperomyzus lactucae (LINNAEUS, 1758) & & & & + & \\
\hline 36. & H. pallidus HILLE RIS LAMBERS, 1935 & & & & + & \\
\hline 37. & H. picridis (BÖRNER \& BLUNCK, 1916) & & & & + & \\
\hline 38. & H. rhinanthi (SCHOUTEDEN, 1903) & & & & + & \\
\hline 39. & Longicaudus trirhodus (WALKER, 1849) & & & & & + \\
\hline 40. & Macrosiphum euphorbiae (THOMAS, 1878) & & & & & + \\
\hline 41. & M. funestum (MACCHIATI, 1885) & & & + & & \\
\hline 42. & M. rosae (LINNAEUS, 1758) & & & & & + \\
\hline 43. & Maculolachnus submacula (WALKER, 1848) & & & & & + \\
\hline 44. & Melanaphis pyraria (PASSERINI, 1861) & & + & & & \\
\hline 45. & Metopolophium dirhodum (WALKER, 1849) & & & & & + \\
\hline 46. & Myzaphis bucktoni JACOB, 1946 & & & & & + \\
\hline
\end{tabular}


Table 1. Continued.

\begin{tabular}{|l|l|c|c|c|c|c|}
\hline No & \multicolumn{1}{|c|}{ Aphid species } & A & B & C & D & E \\
\hline 47. & Myzaphis rosarum (KALTENBACH, 1843) & & & & & + \\
\hline 48. & Myzus cerasi (FABRICIUS, 1775) & + & & & & \\
\hline 49. & M. lythri (SCHRANK, 1801) & + & & & & \\
\hline 50. & M. persicae (SULZER, 1776) & + & & & & \\
\hline 51. & Nasonovia ribisnigri (MOSLEY, 1841) & & & & + & \\
\hline 52. & Ovatus insitus (WALKER, 1849) & & + & & & \\
\hline 53. & Phorodon humuli (SCHRANK, 1801) & + & & & & \\
\hline 54. & Rhopalosiphoninus ribesinus (VAN DER GOOT, 1912) & & & & + & \\
\hline 55. & Rhopalosiphum insertum (WALKER, 1849) & & + & & & \\
\hline 56. & R. nymphaeae (LINNAEUS, 1761) & + & & & & \\
\hline 57. & R. padi (LINNAEUS, 1758) & + & & & & \\
\hline 58. & Sitobion fragariae (WALKER, 1848) & & & + & & \\
\hline
\end{tabular}

Eight aphid species have been reported inhabiting plum trees in Lithuania: Hyalopterus pruni, Phorodon humuli, Brachycaudus cardui, B. divaricatae, B. helichrysi, Rhopalosiphum nymphaeae, R. padi and Aphis spiraecola. The most common aphid species inhabiting plums during the last four decades were Hyalopterus pruni, Brachycaudus divaricatae, Phorodon humuli and Brachycaudus cardui (RAKAUSKAS 1978, 1980, 1983a, RAKAUSKAS et al. 2015b).

Hyalopterus pruni is the only representative of the genus Hyalopterus KoCH, 1854 that is present in Lithuania and the entire eastern Baltic region. The morphological features, biology and ecology of Lithuanian populations of $H$. pruni have been the subject of detailed studies. These populations of $H$. pruni are reported as being capable of living on plums throughout the season, including the production of oviparous females on winter hosts; males appear on secondary hosts (Phragmites ADANSON, 1763) only, however (RAKAUSKAS 1983a, 1983b, ZAREMBA 2012). Partial mitochondrial COI gene sequences did not reveal any specificity of Lithuanian populations of $H$. pruni when compared to those from other regions of Europe (RAKAUSKAS et al. 2013). Brachycaudus cardui is the most common native aphid species of the genus Brachycaudus VAN DER GOOT, 1913 inhabiting plums in Lithuania. The biology and ecology of this country's populations of B. cardui have been studied by RAKAUSKAS (1983a). From 2002 onwards, the alien species B. divaricatae appeared to be the most common one on cherry plums in Lithuania and the entire eastern Baltic region (RAKAUSKAS \& CICHOCKA 2005). A distinctive feature of the Lithuanian populations of $B$. divaricatae is that they are monoecious holocyclic on cherry plums, avoiding migration to the principal summer host plant of this aphid species, Silene alba (MILLER, 1768) (RAKAUSKAS \& TURČINAVIČIENĖ 2006). On the molecular level, these 
populations of $B$. divaricatae appeared to be extremely monomorphic in their partial

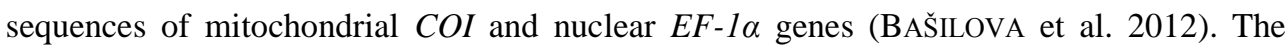
most recent studies have revealed that, despite population outbreaks, $B$. divaricatae did not have any distinct negative effect on the plum aphid guild structure in Lithuania (RAKAUSKAS et al. 2015b). This is partially explainable by the ability of the local ladybird species to prey on $B$. divaricatae (DANILOV \& RAKAUSKAS unpublished). Life cycle studies of Phorodon humuli in Lithuania showed that this species was capable of living on plums during the entire season, including the production of oviparous females on winter hosts, with males appearing on secondary hosts (Humulus LinNAEUS, 1753) only (RAKAUSKAS 1983a). Nonetheless, recent studies have shown $P$. humuli to be extremely rare on plums in Lithuania after the end of June in 2012-2014. This is not explainable by migration to summer hosts, because in the same years $P$. humuli was also rare on its summer hosts in summer (RAKAUSKAS unpublished).

Four aphid species have been reported inhabiting species of the genus Cerasus MILLER, 1754 in Lithuania: Myzus cerasi, M. lythri, M. persicae and Brachycaudus divaricatae. The most common aphid species inhabiting cherries in Lithuania during the last four decades has been Myzus cerasi. Mahaleb cherry serves as a host for M. lythri, but no outbreaks of this aphid species have been recorded in this country as yet. Brachycaudus divaricatae and Myzus persicae are assumed to be occasional species, extremely rare on Cerasus spp. in Lithuania. Available morphological, ecological and molecular (partial mitochondrial COI gene sequences) data suggest the existence of two host-specific subspecies of $M$. cerasi in Lithuania (RAKAUSKAS 1984, RAKAUSKAS et al. 2014a). The country's populations of $M$. cerasi appeared capable of living on cherries throughout the season, including the production of oviparous females on winter hosts; the males emerge on secondary hosts only (RAKAUSKAS 1984).

Ten aphid species have been reported as inhabiting apple trees in Lithuania: Aphis pomi, A. spiraecola, Dysaphis affinis, D. anthrisci, D. brancoi, D. devecta, D. plantaginea, Eriosoma lanigerum, Rhopalosiphum insertum and Ovatus insitus. The most common aphid species inhabiting apple trees in Lithuania during the last four decades have been Aphis pomi, Dysaphis plantaginea and Rhopalosiphum insertum (RAKAUSKAS 1978, 1980, RAUDONIS et al. 2009). Detailed studies of Lithuanian populations of Aphis pomi (RAKAUSKAS \& RUPAIS 1983) showed their biological and ecological characters to be similar to those summarized by BLACKMAN \& EASTOP (2000). On the molecular level, sampled Lithuanian populations appeared identical in their partial nuclear EF-1 $\alpha$ gene sequences: most of the samples had the predominant European haplotype of the mitochondrial COI gene (RAKAUSKAS et al. 2015a). Molecular data also confirmed the existence of A. spiraecola in Lithuania. Most of the Lithuanian samples of this species had the common and widely distributed (Europe, Turkey, China) haplotypes of the 
mitochondrial $C O I$ and nuclear $E F-1 \alpha$ genes. The length of the ultimate rostral segment appeared to be the most reliable morphological character for discriminating between A. pomi and A. spiraecola in Lithuania, enabling $100 \%$ correct identification of the former $(\mathrm{n}=143)$ and $91.5 \%$ of the latter $(\mathrm{n}=94)$ species in the samples used for the molecular analysis (RAKAUSKAS et al. 2015a). The coexistence between these two Aphis LinNAEUS, 1758 species is challenging for pest aphid management practice, because both species are similar in their morphology but differ in their ecological features and resistance to pesticides. Therefore, competitive displacement of A. pomi by A. spiraecola is reported as mediated by human activities in North America (SMIRLE et al. 2010). The life cycle and host specificity of the Lithuanian populations of Dysaphis plantaginea appeared to be similar to those described by BLACKMAN \& EASTOP (2000). This species can thrive on apple till the end of the season in Lithuania, but gynoparous females and males emerge on summer hosts only. Experimental transfers showed Plantago lanceolata LINNAEUS, 1753 to be the preferred summer host of $D$. plantaginea in Lithuania (RAKAUSKAS 1983a). The life cycle and host specificity of Lithuanian populations of Rhopalosiphum insertum appeared similar to those described by BLACKMAN \& EASTOP (2000). This species is the first of the apple aphids to hatch from overwintering eggs in Lithuania and also the first one to emigrate completely from apple to summer hosts (RAKAUSKAS 1983a). Dysaphis anthrisci, D. brancoi, D. devecta, and Ovatus insitus are currently uncommon on apple trees in Lithuania. Eriosoma lanigerum was reported as an accidental species introduced with plant material to Lithuania (ITOMLENSKIS \& BAGDONAS 1936), but there is no information on stable local populations of this species in this country at present. Dysaphis affinis is reported to be monoecious on Malus spp. in Asia (west Siberia, Turkey, Armenia, Georgia, Kazakhstan, Tajikistan, Pakistan, north-west China) (BlACKMAN \& EASTOP 2000). Our data show that this species is rather common on wild apple seedlings living in red leaf galls in Lithuania (RAKAUSKAS 1983a, also more recent unpublished data).

Nine aphid species have been reported inhabiting pear trees in Lithuania: Anuraphis catonii, A. farfarae, A. subterranea, Aphis craccivora, A. pomi, Dysaphis pyri, Eriosoma lanuginosum, Rhopalosiphum insertum and Melanaphis pyraria. The most common aphid species inhabiting pear trees in Lithuania during the last four decades have been Anuraphis farfarae, Aphis pomi and Dysaphis pyri (RAKAUSKAS 1978, 1980, 2004). Anuraphis farfarae is present on pear trees early in the season, completing its emigration to summer hosts by the middle of June (RAKAUSKAS 1983a). Dysaphis pyri was reported to have population outbreaks on pear trees in Lithuania (RAKAUSKAS 2004, also more recent unpublished data), but at present there is no evidence for permanently established populations of this species in the country. The other species of those mentioned above are rare on pear trees in Lithuania, whilst Aphis craccivora should be regarded as an accidental one. Eriosoma lanuginosum has been found on the roots of pear tree in Lithuania only once 
(RAKAUSKAS 1983); earlier records (just four altogether) concern its secondary host, Ulmus spp. (MovŠOVIČIUS 1941, RUPAIS 1966, RUPAIS \& JURONIS 1983a).

Sixteen aphid species have been reported inhabiting Ribes spp. in Lithuania: Aphis grossulariae, A. schneideri, A. triglochinis, Cryptomyzus galeopsidis, C. korschelti, C. maudamanti, C. ribis, Eriosoma grossulariae, E. ulmi, Hyperomyzus lactucae, H. pallidus, H. picridis, H. rhinanthi, Nasonovia ribisnigri and Rhopalosiphoninus ribesinus. The most common aphid species inhabiting currants and gooseberries during the last four decades were Aphis grossulariae, A. schneideri, Cryptomyzus ribis, Eriosoma ulmi and Hyperomyzus lactucae (RAKAUSKAS 1983, BAŠILOVA 2006, 2010a). Species of the genus Aphis have been the subject of detailed morphological, taxonomic, life cycle and host specificity studies (RAKAUSKAS 1983a, 1993, 2000, 2003a, TURČINAVIČIENĖ 2000, 2004, RAKAUSKAS et al. 2011). Contrary to common knowledge (BLACKMAN \& EASTOP 2000), Lithuanian populations of $A$. grossulariae are associated mostly with the winter host plants of the Ribesia section in the Ribesia JANCZEWSKI, 1907 subgenus of the genus Ribes (redcurrants and related species) and are facultatively heteroecious (capable of completing their entire life cycle on currants). The possibility of hybridization between A. grossulariae and A. schneideri in Lithuania and Poland has been demonstrated by experimental hybridization experiments (RAKAUSKAS 1999, 2003a, TURČINAVIČIENĖ 2000). Obligatively and facultatively heteroecious lineages were reported in Lithuanian populations of Cryptomyzus ribis, the latter ones producing both winged and apterous males (RAKAUSKAS 1986, BAŠILOVA 2010b). Winged fundatrigeniae of facultatively heteroecious lineages of C. ribis are only capable of feeding on summer host plants, whilst apterous fundatrigeniae continue their life cycle on currants. Winged fundatrigeniae of facultatively heteroecious lineages of $C$. galeopsidis are capable of feeding on both currants and summer host plants (BAŠILOVA 2010b). Molecular phylogenetic studies of the genus Cryptomyzus OeSTLUND, 1922 showed that the partial sequences of mitochondrial COI gene were of little discriminative value for separating the closely related species of $C$. galeopsidismaudamanti and $C$. korschelti-ribis complexes when compared with partial sequences of the nuclear $E F-1 \alpha$ gene (BAŠILOVA 2010b).

Six aphid species have been reported inhabiting Rubus spp. in Lithuania: Amphorophora idaei, A. rubi, Aphis idaei, A. ruborum, Macrosiphum funestum and Sitobion fragariae. The most common aphid species inhabiting Rubus spp. in Lithuania during the last four decades was Aphis idaei (RAKAUSKAS 1983a). Rearing experiments showed the existence of virgino-sexuparous females (producing viviparous and oviparous females, also males) in the country's populations of A. idaei.

Seven aphid species have been reported inhabiting Rosa spp. in Lithuania: Chaetosiphon tetrarhodum, Longicaudus trirhodus, Macrosiphum rosae, M. euphorbiae, Maculolachnus submacula, Metopolophium dirhodum, Myzaphis bucktoni and M. rosarum. 
The most common aphid species inhabiting Rosa spp. in Lithuania during the last four decades was Macrosiphum rosae (RAKAUSKAS 1983a, RAKAUSKAS \& ZAJANČKAUSKAS 1983, RAKAUSKAS unpublished). This species lives on wild and cultivated roses throughout the season, and is capable of completing its entire cycle by producing sexual morphs on these plants. In Lithuania the possible summer host plant of M. rosae, Knautia arvensis (LINNAEUS, 1753) COULTER, 1823, is mostly inhabited by another closely related species, M. knautiae Holman, 1972 (RAKAUSKAS 1985, 2003a). The same holds for Belarus (BUGA et al. 2012). Molecular phylogenetic studies of the $M$. rosae species complex showed the above species to be different in their EFl $\alpha$ sequences, but nearly identical in their $C O I$ sequences (TURČINAVIČIENĖ \& RAKAUSKAS 2009).

\section{ACKNOWLEDGEMENTS}

My sincere gratitude goes to my supervisors and colleagues, who gave me their encouragement and methodological support while I was performing aphid research in Lithuania during the last four decades. The late Amands RUPAIS (1930-2008), the former Head of the Plant Protection unit of the Botanical Garden of the Latvian Academy of Sciences was my supervisor, who made a substantial contribution to the success of my $\mathrm{PhD}$ studies (1977-1981) and encouraged me to continue aphid studies after graduation. Sincere thanks are due to the late Jaroslav HoLMAN (1931-2014), who supported me with the necessary publications, encouragement and relevant suggestions concerning aphid research from 1980 onwards. Discussions with him, and with his colleagues Petr STARÝ and Jan HAVELKA in the Laboratory of Aphidology of the Institute of Entomology in Česke Budejovice in accordance with the Czech Academy of Sciences/Lithuanian AS exchange Programme (2000-2007) are hard to underestimate. The community of aphid researchers of Poland deserves particular attention. Professor Wacław WOJCIECHOWSKI was my cheerful scientific supervisor during internships at the Department of Zoology at the Silesian University in 1987 and 1995. The Head of the Department (then also Rector of the Silesian University), Professor Sędzimir Maciej KLIMASZEwSKI and his staff (Andrzej CZYLOK, Jacek GorCZYCA, Aleksander HerCZeK, Piotr WęGIEREK, Roman HAŁAJ), provided me with all the necessary equipment and methodological support, as well as an extremely hospitable entourage for the aphid research on site and aphid collecting trips. As a result of their kindness, comparative studies of Polish and Lithuanian aphid material appeared possible. Participation in the Polish Aphidological Symposia (1996-2015) organized by the Polish Aphidological Group (nowadays the Hemipterology Section of the Polish Entomological Society) gave me a unique opportunity of increasing my aphidological knowledge and discussing results with competent colleagues. Professors Elżbieta 
CICHOCKA and Wojciech GOSZCZYŃSKI were my genial hosts enabling my participation in most of these symposia. Of course, the typically Polish cheerfulness of local organizers of the respective symposia was very important. All this resulted in forging close relationships with colleagues from Poland, including also the younger generation of aphid researchers. The hospitality of Roger BLACKMAN and the late Victor EASTOP (1924-2012) during my visits to their laboratory in the British Museum (Natural History) on the occasion of exchange visits between the Royal Society and the Lithuanian AS, also the Oxford and Cambridge hospitality schemes (1996, 1999, 2000, 2001), their kindness in providing me with the necessary publications, consultations regarding the identification of aphid material, also suggesting and discussing aphid research topics was and still is of great importance. My thanks also go to Juan Manuel NiETo NAFria (Leon, Spain), Sebastiano BARBAGALlo and Giuseppe Cocuzza (Catania, Italy), Ole E. HeIE (Copenhagen, Denmark), the late (1922-2014) Georges Remaudiere (Paris, Italy), Andrew Jensen (Moses Lake, WA, USA), Andrey StekolshchiKov and the late (1915-1997) Georgyi Ch. Shaposhnikov (St. Petersburg, Russia), Sergey Buga (Minsk, Belarus) and Vidmantas JURONIS (Kaunas, Lithuania) for their kind cooperation by providing necessary references, aphid material, and discussing current research topics and methodology. From 1980 onwards, the contribution of my MSc and PhD students at the Department of Zoology of Vilnius University (listed as co-authors in the relevant references) was of great importance, especially in their implementation of molecular research tools.

\section{REFERENCES}

BAŠILOVA J. 2006. Currant inhabiting aphids of Lithuania (Hemiptera, Sternorrhyncha: Pemphigidae, Aphididae). MSc thesis, Vilnius University. (in Lithuanian)

BAŠILOVA J. 2010a. The application of discriminant analysis to identify Cryptomyzus aphids. Žemdirbystè=Agriculture 97(4): 99-106.

BAŠILOVA J. 2010b. Biosystematic study of the aphid (Hemiptera, Sternorrhyncha: Aphididae) genus Cryptomyzus Oestlund, 1922 in Lithuania. PhD thesis, Vilnius University. (in Lithuanian)

Bašilova J., Havelka J., Rakauskas R., Starý P., TurČInAviČIEnĖ J. 2012. New information on the invasive to Europe aphid species Brachycaudus divaricatae SHAPOSHNIKOV, 1956 (Hemiptera: Aphididae). Biologia (Bratislava) 67(5): 959-965.

BAŠILOVA J., RAKAUSKAS R. 2007. The genus Cryptomyzus in Lithuania: the species list, biology and distribution. Acta zoologica Lituanica 17(4): 263-271.

BAŠILOVA J., RAKAUSKAS R. 2012a. Morphological separation of aphid species Cryptomyzus leonuri BozhKo, 1961 and Cryptomyzus alboapicalis (THEOBALD, 1916) (Hemiptera: Sternorrhyncha: Aphididae). Biologia (Bratislava) 67(5): 953-958. 
BaŠIlova J., RAKAuskas R. 2012b. Phylogenetic relationships of Dysaphis pyri (BOYER DE FonsColOMBE) and Dysaphis reaumuri (MORDVILKo) (Hemiptera, Sternorrhyncha: Aphididae): COI and EF-1 $\alpha$ evidence. Organisms diversity \& evolution 12(2): 197-204.

BaŠIllova J., RAKauskas R. 2012c. The first record of aphid Melanaphis pyraria (PASSERINI) in Lithuania. Žemdirbystè=Agriculture 99(2): 209-212.

BaŠILOVA J., TuRČInAVIČIENĖ J., RAKAuSKas R. 2008. Karyotypes of seven European aphid species of the genus Cryptomyzus (Hemiptera, Sternorrhyncha: Aphididae). Ekologija (Vilnius) 54(4): $256-259$.

Buga S., Voronova N., RAKauskas R. 2012. Aphid species of genus Macrosiphum Passerini, 1860 (Hemiptera, Sternorrhyncha: Aphididae) inhabiting Knautia L. in Belarus. Zoology and Ecology 22(1): 51-56.

BLACKMAN R.L., EASTOP V.F. 2000. Aphids on the World's Crops: An Identification and Information Guide. 2nd edn. J. Wiley \& Sons, Chichester.

ITOMLENSKIS M., BAGDONAS S. 1936. Gardening. Spindulio, Kaunas. (in Lithuanian)

KRIŠČIŪNAS J. 1913. Diseases of plants. Lietuvos ūkininkas, Vilnius. (in Lithuanian)

MASTAUSKIS S., VilKAitiS V. 1929. Diseases and pests of horticulture and their management. Žemès Ūkio Rūmai, Kaunas. (in Lithuanian)

MovŠOviČIUS J. 1941. Some new zoocecidia from Lithuania. Vilniaus universiteto Matematikos Gamtos fakulteto darbai Biologijos skyrius 1(14): 145-148. (in Lithuanian)

OGIJEWICZ B. 1929. Pests of horticultural and agricultural crops registered in Wilno district in 1928. Prace Towarzystwa Przyjaciół nauk w Wilnie 5: 143-159. (in Polish)

OGIJEwicz B. 1931. Pests of horticultural and agricultural crops registered in Wilno district in 1929. Prace Towarzystwa Przyjaciół nauk w Wilnie 6: 117-123. (in Polish)

RAKAUSKAS R. 1978. Dendrophilous aphides in the gardens of south-east and north Lithuania. Lietuvos TSR aukštujų mokyklų mokslo darbai Serija biologija 16(2): 53-57. (in Russian)

RAKAUSKAS R. 1980. Aphides on fruit-trees and fruit-bearing shrubs of south-east Lithuania. Lietuvos TSR Mokslų akademijos darbai C serija 2(90): 33-44. (in Russian)

RAKAUSKAS R. 1981. Orchard aphides in the fauna of Lithuanian SSR. Trudy Vsesojuznogo Entomologicheskogo obshchestva 63: 49-51. (in Russian)

RAKAUSKAS R. 1983a. Aphides on fruit-trees and fruit-bearing shrubs in Lithuanian SSR. PhD Thesis, Institute of Zoology and Physiology, Moldavian Academy of Sciences. (in Russian)

RAKAUSKAS R. 1983b. Biology and natural enemies of the mealy plum aphid in the Lithuanian SSR. [in:] A.A. RupAIS, Z.D. SpURIS, G.Ch. ShAPOSHNIKOV (eds.). Systematics and ecology of pest aphids. Abstracts of the first all union aphidological Symposium. Zinatne, Jurmala, 57-58. (in Russian)

RAKAUSKAS R. 1984. Bionomics and ecology of the black cherry aphid in the Lithuanian SSR. Lietuvos TSR Mokslų akademijos darbai C serija 4(88): 80-87. (in Russian)

RAKAUSKAS R. 1986. Bionomics and ecology of the Cryptomyzus ribis in the Lithuanian SSR. Lietuvos TSR Mokslų akademijos darbai C serija 2(94): 57-63. (in Russian) 
RAKaUSKas R. 1993. On the Biology of the Ribes-infesting Aphis species in Central Europe. [in:] P. Kindlman, A.P.G. Dixon (eds.). Critical issues in aphid biology. Proceedings of the $4^{\text {th }}$ international Symposium on aphids. Faculty of Biological Sciences, University of South Bohemia, Česke Budejovice, 113-122.

RAKAUSKAS R. 1996. A new aphid on pears in Lithuania. Aphids and other Homopterous insects 5: $159-164$.

RAKAUSKAS R. 1998. Morphometric analysis of European species of the genus Aphis inhabiting Ribes. European Journal of Entomology 95(2): 239-250.

RAKAUSKAS R. 1999. Hybridisation between Aphis grossulariae and Aphis schneideri (Sternorrhyncha: Aphididae): an experimental approach. European Journal of Entomology 96(4): 401-408.

RAKAUSKAS R. 2000a. Experimental hybridisation between Aphis grossulariae and Aphis triglochinis (Sternorrhyncha: Aphididae). European Journal of Entomology 97(3): 377-386.

RAKAUSKAS R. 2000b. Biosystematic studies of Lithuanian aphids (Hemiptera, Sternorrhyncha: Aphididae). Vilnius University Publishers, Vilnius.

RAKAUSKAS R. 2003a. Natural hybridisation between Aphis grossulariae and Aphis schneideri: morphological evidence (Sternorrhyncha: Aphididae). European Journal of Entomology 100(3): $429-434$.

RAKAUSKAS R. 2003b. Macrosiphum on Knautia in Europe: biology, morphology and systematics, including new synonymy (Hemiptera: Aphididae). Deutsche Entomologische Zeitschrift 50(2): $181-190$.

RAKAUSKAS R. 2003c. Intermediate morphs: a pitfall for aphid taxonomists. Aphids and other Homopterous insects 9: 121-130.

RAKAUSKAS R. 2004. Recent changes in aphid (Hemiptera, Sternorrhyncha: Aphididae) fauna of Lithuania: an effect of global warming? Ekologija (Vilnius) 2004(1): 1-4.

RAKAUSKAS R. 2006. Biodiversity: time for detailed local studies. Biologija (Vilnius) 2006(1): 91-95.

RAKAUSKAS R. 2011. Alien and invasive to Lithuania aphid species (Hemiptera, Sternorrhyncha: Aphididae). Aphids and other Hemipterous insects 17: 23-29.

RAKAUSKAS R. 2014. Aphid (Hemiptera, Sternorrhyncha: Aphidoidea) fauna of Lithuania: current state of knowledge. [in:] J.R. STONIS, S.R. HiLl, A. DišKus, T. AušKALnis (eds.). Selected abstracts and papers of the First Baltic International Conference on Field Entomology and Faunistics. Edukologija, Vilnius, 9-10.

Rakauskas R., Cichocka E. 2005. Aphids inhabiting Prunus in the Eastern Baltic region: present state of knowledge and prospective research. Aphids and other Hemipterous insects 11: 141-152.

RAKauskas R., HAVElKa J., BERNOTIENĖ R. 2014b. Mitochondrial (COI) and nuclear (EF-1 $\alpha$ ) DNA variability of Rhopalosiphum padi (LINNAEUs 1758) and Rhopalosiphum nymphaeae (LINNAEUS 1761) (Hemiptera: Aphididae) in Lithuania. Biologia (Bratislava) 69(12): 1730-1741.

Rakauskas R., Havelka J., Bernotienė R. 2015a. Aphis pomi and Aphis spiraecola (Hemiptera: Sternorrhyncha: Aphididae) in Europe - new information on their distribution, molecular and morphological peculiarities. European Journal of Entomology 112(2): 270-280. 
Rakauskas R., Havelka J., Zaremba A. 2013. Mitochondrial COI and morphological specificity of the mealy aphids (Hyalopterus spp.) collected from different hosts in Europe (Hemiptera, Aphididae). [in:] A. Popov, S. Grozeva, N. Simov, E. Tasheva (eds.). Advances in Hemipterology. ZooKeys 319: 255-267.

Rakauskas R., Havelka J., Zaremba A. 2015b. Plum (Prunus spp.) aphid guild structure in Lithuania (Hemiptera: Sternorrhyncha, Aphididae): any impact of an alien aphid species? Žemdirbystė=Agriculture 102(1): 81-86.

Rakauskas R., Havelka J., Zaremba A., Bernotiené R. 2014a. Mitochondrial COI and morphological evidence for host specificity of the black cherry aphids Myzus cerasi (FABRICIUS, 1775) collected from different cherry tree species in Europe (Hemiptera: Aphididae). ZooKeys 388: $1-16$

RAKAUSKAS R., RUPAIS A. 1983. Biology of the green apple aphid in Lithuania. Acta entomologica Lituanica 6: 20-30. (in Russian)

RAKauskas R., RuPaIS A., JURONIS V. 1992. The Check-list of Lithuanian Aphidoidea. New and rare for Lithuania insect species. Volume 2. Records and descriptions of 1992: 83-100.

RAKAuskas R., TURČInAVIČIENĖ J. 1998. New colour form of Aphis schneideri (BöRn.) from Lithuania. Acta Zoologica Lituanica. Entomologia 8(3): 3-8.

RAKAUSKAS R., TURČINAVIČIENĖ J. 2006. Brachycaudus divaricatae SHAPOSHNIKOV, 1956 in Europe: biology, morphology and distribution, with comments on its taxonomic position (Hemiptera, Sternorrhyncha: Aphididae). Mitteilungen aus dem Museum für Naturkunde in Berlin, Zoologische Reihe 82(2): 248-260.

RAKAUSKAS R., TURČINAVIČIENĖ J., BAŠILOVA J. 2011. How many species are there in the subgenus Bursaphis MCVICAR BAKER, 1934 (Hemiptera, Sternorrhyncha: Aphididae): CO-I evidence. European Journal of Entomology 108(3): 469-479.

RAKAUSKAS R., ZAJANČKAUSKAS P. 1983. Biological peculiarities of the rose aphid in the Lithuanian SSR. Lietuvos TSR Mokslų akademijos darbai C serija 2(82): 70-78.

RAudonis L., VAliušKaitė A., Duchovskienė L., SURVILIENĖ E. 2009. Toxicity of biopesticides in green apple aphid. Sodininkyste ir daržininkystė 28(3): 173-179.

RUPAIS A. 1966. Materials concerning dendrophilous aphid fauna (Homoptera, Aphidoidea) of Lithuania. I. Aphides on the deciduous trees and shrubs. Latvijas Entomologs 11: 31-47 (in Russian)

RUPAIS A.1971. An outcome of the aphid studies on the leafbearing trees and shrubs in the Baltic region. [in:] K. OzoLIONIS (ed.). Botanical gardens of the Baltic region. Zinatne, Riga, 171-184. (in Russian)

RUPAIS A., JURONIS V. 1983a. Aphides found in Kaunas and its environs in 1963-1980. Lietuvos TSR Mokslų akademijos darbai C serija 2(82): 63-69 (in Russian)

RUPAIS A., JURONIS V. 1983b. Aphides found in Kaunas and its environs in 1963-1980. Lietuvos TSR Mokslų akademijos darbai C serija 3(83): 57-65 (in Russian)

RUPAIS A.1969. Atlas of the Baltic dendrophilous plantlice (Plantlice of leaf-bearing trees and shrubs). Zinatne, Riga. (in Russian) 
Smirle M. J., Zurowski C. L., Lowery D.T., Foottit R. G. 2010. Relationship of insecticide tolerance to esterase enzyme activity in Aphis pomi and Aphis spiraecola (Hemiptera: Aphididae). Journal of Economic Entomology 103(2): 374-378.

TRZEBIŃSKI J. 1916. Zoocecidia collected in the Kowno region and Poląga (Contribution to the zoocecidiology of Lithuania). Pamiętnik Fizjograficzny 23: 238-246. (in Polish)

TURČINAVIČIENĖ J. 2000. Biosystematic study of the aphid genus Aphis L. grossulariae group (Hemiptera, Sternorrhyncha: Aphididae). PhD Thesis, Vilnius University. (in Lithuanian)

TURČINAVIČIENĖ J. 2004. Host plant specificity, life cycle and morphometric analysis of Ribesinhabiting species of the genus Aphis L. [in:] J.-Ch. SimON, Ch.-A. DedRYver, C. Rispe, M. HulLE (eds.). Aphids in a new millenium. INRA, Paris, 97-101.

TURČINAVIČIENĖ J., RAKAUSKAS R. (2009). Macrosiphum on Knautia in central Europe - molecular data support the synonymy of M. silvaticum and M. knautiae (Hemiptera Aphididae). Redia 92: $105-109$.

TURČINAVIČIENĖ J., RAKAUSKAS R., LAZUTKA J. 1997. Karyotypes of three aphid species: Aphis triglochinis, Aphis grossulariae and Aphis schneideri. Biologija (Vilnius) 4: 60-62.

TurČInaviČIené J., Rakauskas R., Pedersen B. V. 2006. Phylogenetic relationships in the „grossulariae“ species group of the genus Aphis (Hemiptera: Sternorrhyncha: Aphididae): Molecular evidence. European Journal of Entomology 103(3): 597-604.

TURČINAVIČIENĖ J., SUŽIEDĖLIS K., RAKAUSKAS R. 1999. DNA study of the currant inhabiting species of the genus Aphis L. by means of the randomly amplified polymorphic DNA polymerase chain reaction (RAPD-PCR). Acta Zoologica Lituanica 9(1): 178-182.

Vengeliauskaitė A. 1962. Pests of ornamental plants at the Kaunas Botanical Garden of the Academy of Sciences of the LitSSR. [in:] A. MARLAND (ed.). Proceedings of Baltic conference on plant protection. Hans Heidemann, Tallinn, 223-226 (in Russian)

ZAREMBA A. 2012. Study of the Hyalopterus pruni species complex in the Eastern Baltic region. MSc Thesis, Vilnius University. (in Lithuanian)

Received: 3 July 2015

Accepted: 27 July 2015 